\title{
KÜLÖNLEGES LŐFEGYVERCSÖVEK KÁROSODÁSELEMZÉSE
}

\section{FAILURE ANALYSIS OF HIGH PERFORMANCE GUN-BARRELS}

\author{
Kovács Dorina $^{1}$, Dobránszky János ${ }^{2}$ \\ ${ }^{I}$ BME Gépészmérnöki Kar, Anyagtudomány és Technológia Tanszék, Magyarország, \\ 1111 Budapest, Müegyetem rakpart 3.tel:+361463-1114, dorina@eik.bme.hu \\ ${ }^{2}$ MTA-BME Kompozittechnológiai Kutatócsoport, Magyarország, 1111 Budapest, \\ Müegyetem rakpart 3.tel: +361463-1934,dobranszky.janos@eik.bme.hu
}

\begin{abstract}
The riffle has some main parts: the barrel, which controls the way of bullet; the cock primes the shot; the gunlock closes the backside of the barrel; the stock unites the parts of weapon and the sights used for aiming. The mostly damaged part is the barrel, especially inside, because the steel is corroded by the gases from the burning of powder. Besides the friction between the bullet and the wall, the high temperature and the atmospheric corrosion cause failures too. Scanning electron microscope and EDS analysis were used for the chemical composition analysis than LECO CS-400 Carbon Sulfur Analyzer for determining the carbon and sulphur content. Cross-sectional and longitudinal cut specimens were prepared for the analyses. Pollution and combustion products on the surface were analysed with SEMEDS and X-ray diffractometry. During the metallographic investigation a characteristic crack network was revealed in case of samples coming from hybrid barrel at its firing chamber.
\end{abstract}

Keywords: failure analyses, barrel, corrosion

\section{Összefoglalás}

Azokat a távolra ható fegyvereket nevezik lőfegyvereknek, melyek csövéből a lövéskor keletkező gázok feszítőereje löki ki a fémből készült lövedéket. Egy kézi lőfegyver több fő részből épül fel: a puskacső, amely vezeti a lövedéket; a kakas, mely a lőpor meggyújtási folyamatát indítja el; a závárzat, mely a cső hátulsó részét zárja el; az ágy, ami egybefoglalja a különböző alkatrészeket; valamint az irányzókészülék, ami a célbavételt segíti. A károsodásnak leginkább kitett alkatrésznek mindenképpen a puskacső - annak is a csőfurat felülete - bizonyul, hiszen a puskapor égéséből keletkező gázok maró hatással lehetnek a fémre. A lövedék súrlódása a cső falával, valamint a nagy hőmérsékleti és a légköri korrózió is problémákat okozhat. Három puskacső anyagának azonosítását és károsodáselemzését végeztük el. Mivel a puskacsövet az elején és végén különböző mértékü hatások érik, ezért mindkét végéből történő mintavételezés szükséges. A felületen lerakódott termékek azonosítására elektronmikroszkópot és röntgendiffraktométert használtunk, továbbá metallográfiai vizsgálatot végeztünk.

Kulcsszavak: károsodásanalizis, puskacső, korrózió

\section{A lőfegyverek tönkremenetele}

A puskacső megfelelő ápolása megőrzi a fegyver hosszan tartó pontosságát. A cső gyors állapotromlását a csappantyú és a lőpor égéséből keletkező, igen agresszív maró anyagok okozzák; ezek belülről erősen kor- rodálják a cső falát. Ezenkívül a lövéskor keletkező égéstermékek és a lövedékből származó anyagok lerakódhatnak a huzagolási barázdákba, ezáltal eltömítve a lövedék útját. A lerakódott, kis olvadáspontú anyagok a puskacső falával reakcióba léphetnek, ami korróziós repedéseket okozhat. A löve- 
dék és a fal közötti súrlódás hatására kopás, valamint a gyors hőtágulási ciklusok következtében termikus fáradás is felléphet $[1,2]$.

Kísérletek bizonyították, hogy a fegyverápolás jelentősen megnöveli a fegyver pontosságát. Akár 10000 lövés után is tökéletesen müködik, míg egy kezeletlen fegyver egy vadászszezon alatt tönkremegy.

\section{Kísérletek}

Három, különböző méretü és anyagú puskacsővel dolgoztunk. A mintavételezés során (1.ábra) hütés nélküli forgácsolást alkalmaztunk, aminek az az értelme, hogy a puskacsövön lerakódott szennyeződések ne tünjenek el a vízzel történő hütés következtében, illetve további korrózió és egyéb szennyeződés ne keletkezzen az anyagon.

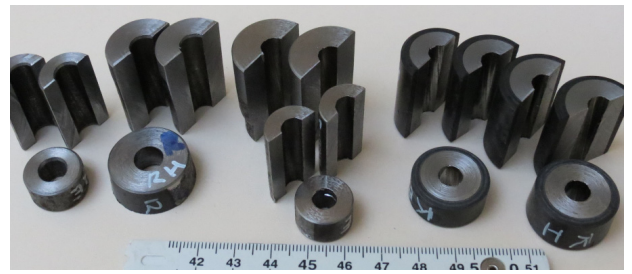

1. ábra A puskacsövekből esztergálással és fürészeléssel kivágott vizsgálati minták

A mintákat a puskacsövek torkolatától (a továbbiakban: eleje) és a töltényür felöli végéből (a továbbiakban: hátulja) vettük, összehasonlítva az eltéréseket.

\subsection{Mikroszkópi vizsgálat}

A puskacsőanyagok kémiai összetételének spektrométeres elemzésével - az 1. és a 2. táblázat adataiból - megállapítottuk, hogy egy cső anyaga nemesíthető acél, kettőé pedig martenzites korrózióálló acél, melyek egyikét kompozitköpeny erősít.

1. táblázat Nemesithető acél anyagösszetétele

\begin{tabular}{|c|c|c|c|c|c|}
\hline $\mathbf{C}$ & $\mathbf{S i}$ & $\mathbf{M n}$ & $\mathbf{C r}$ & $\mathbf{M o}$ & $\mathbf{N i}$ \\
\hline 0,690 & 0,253 & 0,657 & 0,182 & 0,007 & 0,064 \\
\hline
\end{tabular}

2. táblázat $A$ rozsdamentes acél csö összetétele

\begin{tabular}{|c|c|c|c|c|c|}
\hline $\mathbf{C}$ & $\mathbf{S i}$ & $\mathbf{M n}$ & $\mathbf{C r}$ & $\mathbf{M o}$ & $\mathbf{N i}$ \\
\hline 0,240 & 0,54 & 0,83 & 11,97 & 0,102 & 0,094 \\
\hline
\end{tabular}

A mikroszkópi vizsgálatok során a puskacső hátuljánál, azaz a töltényür utáni részen repedéseket észleltünk (2-3. ábra).

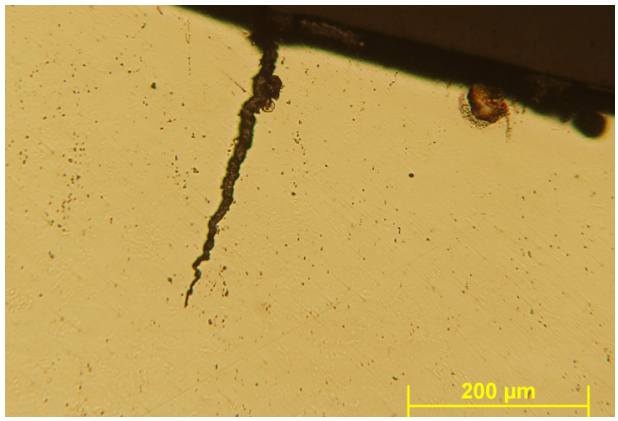

2. ábra. Repedés a maratlan martenzites rozsdamenstes acélon

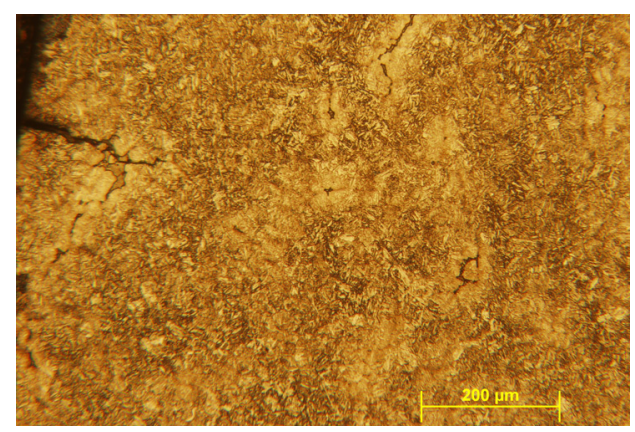

3. ábra Repedések és kiválások hálózata, martenzitesre edzödött részek

A hőfáradás olyan anyagkárosodás, melynek során a ciklikusan váltakozó hőterhelés (hő- és mechanikai terhelés) váltakozó képlékeny alakváltozást idéz elő az anyag felületközeli rétegeiben, a külső és a belső anyagrészek eltérő és akadályozott hőtágulása következtében. A hőlökés hatására kialakuló höfeszültség - különösen egyidejüleg ható mechanikai terheléssel az anyag folyáshatárát elérő feszültséget, az akadályozott alakváltozás pedig repedést, sőt törést eredményezhet. Természetesen a 
visszahülés folyamata levegön lassabban következik be, mint az azonnal fellépő felmelegedés. Ez a jelenség csak a lőpor gyújtásának a helye körül okozott problémát, a puskacső elején repedések már nincsenek $[2,3,4]$.

\subsection{Metallográfiai vizsgálat}

A keménységmérést a puskacső belső furata felőli oldalától kifelé végeztük. A repedésekből kiindulva feltételeztük, hogy a belső átmérő mentén keményebb lesz az anyag, így ennek csökkenése rövid távon bekövetkezik. Beigazolódott, hogy a cső keménysége a belső átmérő mentén valamivel nagyobb, mint a külsejénél, tehát keményedés történt, aminek a hőmérsékletváltozás volt a kiváltó oka. Ez mindegyik mintára igaz, a károsodástól függetlenül.

A hibrid kompozit puskacső hátuljából kivett keresztcsiszolati minta keménységváltozási diagramja látható a 4. ábrán.

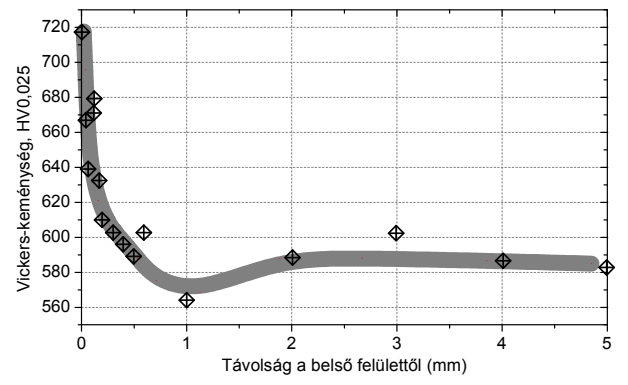

4. ábra Keménységváltozás a kompozitköpenyes hibrid puskacsö acél anyagában

$\mathrm{Az} 590 \mathrm{HV}_{0,025}$ alapkeménységhez képest a $700 \mathrm{HV}_{0,025}$ fölé növekedő keménység oka valószínüleg nem más, mint az újraausztenitesedés utáni edződés. Ez pedig azt is jelenti, hogy a puskacső belső felületének hömérséklete megközelítette az $1200^{\circ} \mathrm{C}$-t, ugyanis a Fe-Cr-C pszeudobinér fázisdiagramok [5] szerint közel ekkora hőmérséklet kell az ausztenitesedés megindulásához.

\subsection{A korróziótermék vizsgálata}

A csőben talált korróziótermék lerakódás vizsgálathoz a hosszmetszeti mintákat használtuk. Mindegyiken megfigyelhetők a huzagolás nyomai, illetve a cső elejétől és hátuljától függően a különböző mértékü lerakódások, illetve néhol a repedések is láthatók.

A puskacső különböző részei jól elkülöníthetők a felvételek alapján: az elején sokkal élesebb az oromzat és a barázda közötti határvonal, míg a hátuljánál az élek sokkal lekerekedettebbek. A repedésekben előszeretettel tapadnak meg az égéskor és a lövedék felületéről felszabaduló anyagok (5. ábra), amelyek fokozhatják a repedésterjedést. Lerakódások mindhárom puskacső belsejében egyaránt fellelhetők [6].

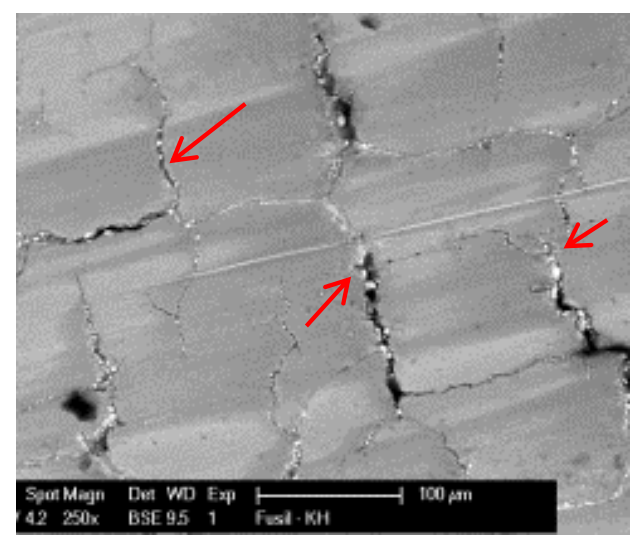

5. ábra A kompozitköpenyes puskacső repedései és a bennük megtapadt lerakódások

A repedésekben megtapadt anyagok összetevőit EDS-sel elemeztük (6. ábra). Az eredményekből kiderült, hogy a lerakódások nem a lőpor égéséből, hanem a lövedékből származó fémes anyagok, pl. ón és ólom kerültek oda, mégpedig olvadék olvadék állapotban.

A lövedék kismértékü képlékeny alakváltozást szenved, hiszen a szakirodalom [7] szerint az ónt a lövedékmag keményítésére használják, de a súrlódásnak és az ebből eredő felmelegedésnek és felületi meg- 
olvadásnak köszönhetően apró szemcsék kiszakadnak belőle a lövés során.

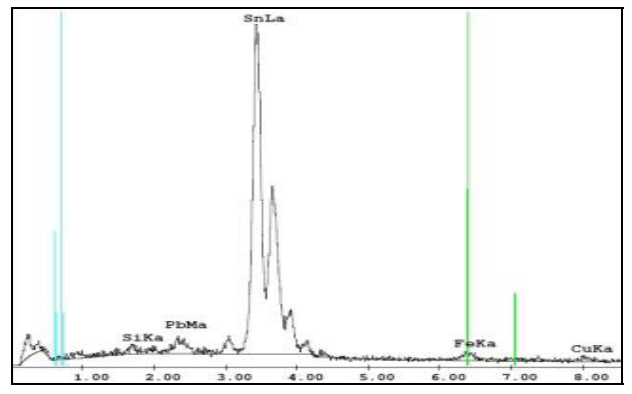

6. ábra $A z$ 5. ábrán látható fehér szinü lerakódások EDS spektruma föleg Sn-t mutat

Az ón jó korrózióálló, nedves levegőn nem oxidálódik, ezenkívül ellenáll a szerves savaknak. A legtöbb lövedék magjának alapanyaga ón-ólom ötvözet, azonban megjelenik mellette réz is, ami szintén a lövedék anyagából származik, hiszen ezek mellett ónbronzokat is alkalmaznak.

$\mathrm{Az}$ ólommal szemben több előnyös tulajdonsága miatt is alkalmazzák manapság az ónbronzokat. Az ónalapú fehérfémek kopásállósága valamivel nagyobb az ólomalapúétól. A súrlódási tényezőjük csökken a hőmérséklet növelésével, ha eközben az ötvözet túlságosan nem lágyul ki. A lágyulás a súrlódási tényező hirtelen növekedését okozza. Kedvezőtlen hőmérsékleti viszonyok között $\left(>80^{\circ} \mathrm{C}\right)$ ónalapú fémet célszerü használni.

\section{Következtetések}

A vizsgálatok során feltárt repedésekből, az edződés hatására kialakuló keménységváltozásokból egyértelmủen megállapítható, hogy a lövedéksúrlódás kiváltotta hömérséklet-változás nagy hatást gyakorol a puskacsövekre. A lövés pillanatában képződő hőt nem lehet jelentősen befolyásolni. Ahhoz, hogy ezek a repedések ne jelenjenek meg, a hőterhelés és a hőfáradás hatását jól bíró anyag kiválasztása vagy a belső felület hőhatására történő érzékenységének csökkentrése a lehetséges elvi megoldás.
A minták között alkalmazott rozsdamentes acél alapanyaga 12\% krómot tartalmaz, erősen ötvözött acélnak minősül, keményebb és szilárdabb anyag a szénacéloknál, mégis ez bizonyult a legsérülékenyebbnek. A felületközeli zóna keményedésének jelensége mindegyiknél fellépett.

Ebből adódik az a következtetés, hogy egy keményebb felületi réteg talán megakadályozhatná, vagy csökkenthetné a repedésképződést.

Ehhez különböző felületkezelési eljárások alkalmazhatók, például a nitridálás. Ennek és más lehetséges felületkezeléseknek a működőképességét a jövőben célszerü kísérletileg is ellenőrizni.

\section{Szakirodalmi hivatkozások}

[1] Piroska Gy: A belballisztika fö feladatának numerikus megoldásra alapuló modell megalkotása porózus löporokra. $\mathrm{PhD}$-értekezés, Zrínyi Miklós Nemzetvédelmi Egyetem, Budapest, 2005.

[2] Artinger I, Kator L, Romvári P: Fémek technológiája. Múszaki Könyvkiadó. Budapest. 1972.

[3] Degerness MK: Composite structural member. US Patent 6889464 B2, 2005.

[4] Olin Mathieson: Composite firearm barrel comprising glass fibers. US Patent US2847786, 1958.

[5] Lima MSF, Espirito Santo AM: Phase transformations in an AISI 410 Stainless steel observed in directional and laser-induced cooling regimes. Mat. Res. vol.15 no.1 São Carlos Jan./Feb. 2012 Epub Jan 31, 2012.

[6] Carbon fibre gun barrel. US Patent, US4646615 1987.

[7] Kovács Dénes: Vadásztöltény-és lötechnikai ismeret. Natur Mühely Kiadó (Budapest), 2004

[8] Szilágyiné Biró A, Nagy D, Kocsisné Baán M: A gáz és plazma közegü karbonitridálás összehasonlitása a kialakult rétegmélység szempontjából. Fiatal Müszakiak Tudományos Ülésszaka XVIII. Kolozsvár, 2013. pp.387-390.

[9] Török T, Barta E: Fémes és szervetlen bevonattechnológiák. Miskolci Egyetem, 2012/2013. 